\title{
Cowpea Response to Two Organic Fertilizers in the Nord Sudan Zone of Burkina Faso
}

\author{
Jean Ouedraogo ${ }^{1}$, Idriss Serme ${ }^{1}$, Désiré Jean Pascal Lompo ${ }^{2}$, Sogo Bassirou Sanon ${ }^{1} \&$ Korodjouma Ouattara ${ }^{1}$ \\ ${ }^{1}$ Institut de l'Environnement et de Recherches Agricoles (CNRST/INERA), Ouagadougou, Burkina Faso \\ ${ }^{2}$ Université de Dédougou, Dédougou, Burkina Faso \\ Correspondence: Idriss Serme, Institut de l'Environnement et de Recherches Agricoles (CNRST/INERA), 01 BP \\ 476 Ouagadougou 01, Burkina Faso. E-mail: sermeidriss@yahoo.fr
}

Received: October 17, 2020

Accepted: November 28, 2020

Online Published: January 15, 2021

doi:10.5539/jas.v13n2p95

URL: https://doi.org/10.5539/jas.v13n2p95

\begin{abstract}
The Intensification of cowpea production is a priority because of its role in household income generation and its contribution to food security. To evaluate the effect of organic fertilizers on cowpea productivity, a dispersed block experiment design was set up in Saria in the semi-arid zone of Burkina Faso during the 2017 and 2018 cropping seasons. The combination of Biodeposit (Agro and Elixir) and Organova were used alone or in combination with mineral fertilizer. The results showed that during the two years, the highest cowpea grain yields were obtained with the Organova + the recommended mineral fertilizer and Biodeposit Agro + the recommended mineral fertilizer. The combination of organic fertilizers and recommended mineral fertilizer resulted in a $45 \%$ and $59 \%$ increase respectively with Organova and Biodeposit (Agro + Elixir). These two fertilizers then have the same effects on cowpea productivity. In the semi-arid zone where there is competition for organic resources, organic fertilizers can be used in combination with mineral fertilizer to improve cowpea productivity.
\end{abstract}

Keywords: cowpea, fertilization, Biodeposit Agro, Biodeposit Elixir, Organova, Burkina Faso

\section{Introduction}

Cowpea is a strategic crop in Burkina Faso. It is an important source of income for households and contributes to food security (Oke \& Eyitayo, 2010). Indeed, its production reached 600,680 tons in 2019. However, the national production of cowpea stagnates with 555833 tons produced in 2017 (INSD, 2018), despite an increase in cowpea production lands by $146 \%$ (INSD, 2018) and the adoption of new and more productive cowpea varieties. This small increase in productivity is due to pests' pressures but especially to low soil fertility. This has been already observed by Lahmar et al. (2011), Bationo et al. (2012), Omotoso (2014), and Bationo and Fening (2018) who noted that the majority of cultivated soils in sub-Saharan Africa have low yields because of their low inherent soil fertility and land degradation.

The increase in crop yields, especially cowpea, depends both on the long-term improvement of soil fertility through the recycling of organic amendments (crop residues, manure, etc.) and the use of fertilizers (Bationo \& Fening, 2018); and on the other hand, the improvement in water use efficiency (Bationo et al., 2007; Lal, 2011). Lal (2006) reported that among the various productivity improvement strategies, the one based on improved soil quality and agronomic productivity per unit area through improved soil organic carbon content has many advantages. Organic matter is both a source and a reservoir of nutrients, and plays a vital role in maintaining soil fertility (Bationo et al., 2007) and in improving agricultural productivity (Lal, 2006). Numerous studies have been conducted on organic cowpea fertilization (El-Sayed \& Abdelnaser 2010; Adeoye et al., 2011; Omotoso, 2014). These studies indicated that organic amendments improve cowpea yields.

The need to sustainably improve agricultural productivity has resulted in high demand for organic matter. Thus, to meet this demand, several companies are producing and promoting organic fertilizers. However, none of the above studies have addressed these organic materials.

This study was conducted to evaluate the performance of different organic fertilizers on cowpea productivity to make recommendations to farmers and policymakers. 


\section{Material and Methods}

\subsection{Site Description}

Field experiments were carried out during two cropping seasons (2017 and 2018) in Saria Research station and farmer's fields around Saria (Centre Ouest region), located in the North-Sudan zone of Burkina Faso. Soils are Lixisols, low in organic matter (organic matter content $<1 \%$ ), and acids ( $\mathrm{pH}<5.8$ ). In 2017, $800.2 \mathrm{~mm}$ of rain over 62 days were recorded while in $2018,836.4 \mathrm{~mm}$ of rain over 68 days were measured. Figure 1 shows the monthly rainfall distribution in 2017 and 2018.

The experiment sites are representative of the north Sudan agricultural land. The results obtained can therefore be extrapolated to the entire zone.

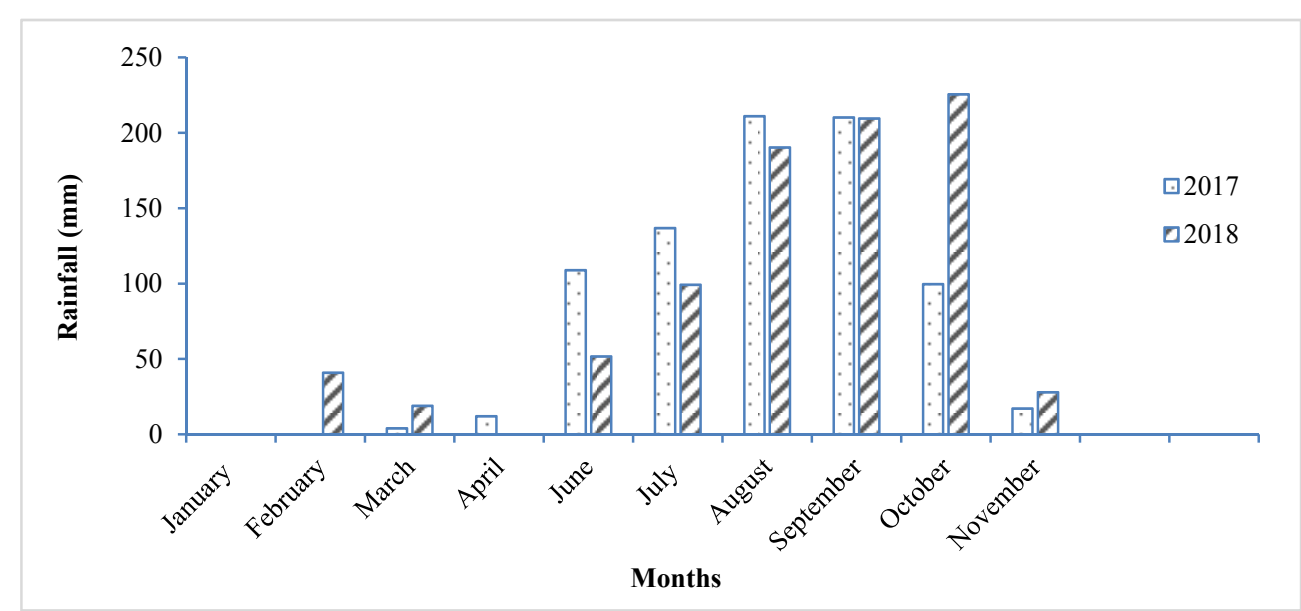

Figure 1. Rainfall distribution in Saria during 2017 and 2018 cropping seasons

\subsection{Organic Fertilizers}

Two organic fertilizers from two industrial companies were evaluated:

- Biodeposit Agro, of the Industrial and Agricultural Company of West Africa (SIAAO) which is a dehydrated Sapropel containing amino acids, antibiotics, vitamins, macro nutrients, secondary and micro nutrients.

- $\quad$ and Organova, from the group "Elephant Vert". ORGANOVA is a 100\% natural organic amendment derived from the recovery of plant residues, livestock manure, and/or by-products of agro-industry, obtained through the organic matter stabilization process.

Table 1 shows the characteristics of organic fertilizers. It appears that except for the nitrogen contents that are similar for the two organic fertilizers, the others nutrient contents of the Organova fertilizer are higher than those of Biodeposit Agro with a $\mathrm{C} / \mathrm{N}$ ratio of 34 .

Table 1. Organic fertilizers characteristics

\begin{tabular}{lll}
\hline Paramètres & Organova & Biodeposit Agro \\
\hline Total organic $\mathrm{C}(\%)$ & 14.4 & 52.4 \\
Total $\mathrm{N}(\%)$ & 1.5 & 1.5 \\
Total $\mathrm{P}_{2} \mathrm{O}_{5}(\%)$ & 2.0 & 0.1 \\
$\mathrm{~K}_{2} \mathrm{O}(\%)$ & 1.4 & 0.1 \\
$\mathrm{C} / \mathrm{N}$ & 10 & 34 \\
$\mathrm{CaO}(\%)$ & 0.5 & 0.1 \\
$\mathrm{MgO}(\%)$ & 0.4 & 0.1 \\
\hline
\end{tabular}

Source: INERA/Laboratoire Sol Eau Plante (2018). 


\subsection{Experimental Design}

On-station, a randomized complete block design with 3 replications was used. In farmers' fields, a dispersed block design with 5 replications where each farmer was considered as repetition was used. The elementary plot size was $6 \mathrm{~m} \times 6 \mathrm{~m}=36 \mathrm{~m}^{2}$

The fertilization treatments were as follows:

T1: Control without fertilizer;

T2: Recommended Mineral Fertilization (100 kg/ha of NPK: 14-23-14);

T3: Biodeposit (Agro + Elixir);

T4: Biodeposit (Agro + Elixir) + Recommended mineral fertilization;

T5: Biodeposit (Agro + Elixir) + 1/2 Recommended mineral fertilization;

T6: Organova;

T7: Organova + Recommended mineral fertilization;

T8: Organova $+1 / 2$ Recommended mineral fertilization.

Biodeposit Agro was used at a rate of $556 \mathrm{~kg} / \mathrm{ha}$ or $2 \mathrm{~kg} / \mathrm{seedling}$. Organova was incorporated in the soil just after emergence at the rate of $2 \mathrm{t} / \mathrm{ha}$. Mineral fertilizer (NPK 14-23-14) was applied at the rate of $100 \mathrm{~kg} / \mathrm{ha}$ at 15 days after sowing (DAS). The rates of organic fertilizers used were those recommended by the companies.

\subsection{Cropping Operations}

The cowpea variety Tiligré (KVX-775-33-2G) with a cycle of 70 days and a potential yield of $2000 \mathrm{~kg} / \mathrm{ha}$ was used. It is an upright variety adapted to the north Sudan zone of Burkina Faso. The sowing was carried out during the first decade of July at a spacing of $80 \mathrm{~cm} \times 40 \mathrm{~cm}$. The sowing was preceded by plowing using animal traction. Three weeding have been carried out, the first at 15 day after sowing (DAS), the second and the third at 30 DAS, and 45 DAS respectively. Two phytosanitary treatments were done using Deltaméthrine (Decis), respectively at flowering and pods initiation, at the recommended rates. For Biodeposit Agro-treated plots, Biodeposit Elixir, a growth accelerator concentrated vitamin capable of sustainably activating the natural plant defense system and containing $123 \mathrm{~g}$ of wet acid per kilogram, was used at a rate of $13 \mathrm{~L} / \mathrm{ha}$. Biodeposit Elixir protects cowpea crops against pests. The treatments were carried out as soon as the first leaves appeared and every 2 weeks after the first application at the rate of one sachet diluted in $20 \mathrm{~L}$ of water per plot. On the other hand, no phytosanitary treatment was carried out on the plots that received the Organova fertilizer. The non-application of phytosanitary treatments to the plots that received Organova aimed to compare the effects of Deltaméthrine (Decis) with Biodeposit Agro and Biodeposit Elixir, which can to ensure mineral nutrition and crop protection.

Cowpea grain and biomass yield have been evaluated on $23.04 \mathrm{~m}^{2}$ within the elementary plot.

\subsection{Statistical Analyzes}

Analysis of variance (ANOVA) on cowpea grain and biomass yields were performed using Statistix 10 software. Means Separation was done using Tukey test at $5 \%$ probability.

\section{Results}

\subsection{Fertilization Options Effects on Cowpea Grain Yield}

The analysis of variance did not show any significant difference between cowpea grain yields obtained on the research station compared with those obtained on farmers' fields. In 2017, the highest cowpea grain yields were obtained with Organova + recommended Mineral Fertilizer treatment and Biodeposit (Agro + Elixir) + recommended mineral fertilizer treatments with $976.56 \mathrm{~kg} \mathrm{ha}^{-1}$ and $965.71 \mathrm{~kg} \mathrm{ha}^{-1}$ respectively. The lowest cowpea grain yields were recorded on the control plots with $374.35 \mathrm{~kg} \mathrm{ha}^{-1}$. The combination of organic fertilizers with the recommended mineral fertilizer resulted in an increase of $45.16 \%$ and $58.93 \%$ with Organova and Biodeposit (Agro + Elixir), respectively. Mineral, organo-mineral fertilization resulted in an increase in cowpea grain yield from $62 \%$ to $161 \%$ compared to the control. In 2018 , these increases in cowpea were from $17 \%$ to $152 \%$ respectively (Table 2).

During the two years of data collection; statistical analysis did not show any significant difference between Organova and Biodeposit fertilizers (Agro + Elixir) applied alone on cowpea grain yield, despite the higher nutrient content of Organova. These two fertilizers have then the same effects on cowpea productivity. However, in 2017 with the application of Organova alone, cowpea grain yield was statistically equivalent to the yield obtained 
with the application of the recommended mineral fertilizer as well as that obtained with the application of Organova $+1 / 2$ Recommended mineral fertilizer. In 2018, the application of Biodeposit alone resulted in cowpea grain yield statistically equivalent to those obtained with the recommended mineral fertilizer, Biodeposit + recommended mineral fertilizer and Biodeposit $+1 / 2$ recommended mineral fertilizer. Also, in 2018, it was noted that the yield increases with the application of Organova alone, Organova + Recommended mineral fertilizer, and Organova $+1 / 2$ Recommended mineral fertilizer were statistically similar (Table 2 ).

Table 2. Cowpea grain yield as affected by fertilizer

\begin{tabular}{lll}
\hline Treatments & $\mathbf{2 0 1 7}$ & $\mathbf{2 0 1 8}$ \\
\hline Control (without fertlizer application) & $374.35^{\mathrm{d}}$ & $176.32^{\mathrm{c}}$ \\
Recommended Mineral Fertilizer & $911.46^{\mathrm{ab}}$ & $443.52^{\mathrm{a}}$ \\
Biodeposit (Agro + Elixir) & $607.64^{\mathrm{cd}}$ & $309.25^{\mathrm{abc}}$ \\
Biodeposit (Agro + Elixir) +Recommended Mineral Fertilizer & $965.71^{\mathrm{a}}$ & $387.91^{\mathrm{ab}}$ \\
Biodeposit (Agro + Elixir) + 1/2 Recommended Mineral Fertilizer & $759.55^{\mathrm{abc}}$ & $355.36^{\mathrm{abc}}$ \\
Organova & $672.75^{\mathrm{bc}}$ & $206.16^{\mathrm{bc}}$ \\
Organova + Recommended Mineral Fertilizer & $976.56^{\mathrm{a}}$ & $401.48^{\mathrm{ab}}$ \\
Organova + 1/2 Recommended Mineral Fertilizer & $661.89^{\mathrm{c}}$ & $311.96^{\mathrm{abc}}$ \\
\hline Probability & $<0.0001^{\mathrm{abc}}$ & 0.0003 \\
\hline
\end{tabular}

Note. The means followed by the same letter are not significantly different at $5 \%$ probability.

\subsection{Fertilization Options Effect on Cowpea Biomass Yield}

The best cowpea biomass yield was obtained in 2017 with Organova + recommended Mineral Fertilizer treatment with $1350.9 \mathrm{~kg} \mathrm{ha}^{-1}$ which was significantly different from that of the control. It was followed by the recommended mineral fertilizer treatment with $1242.4 \mathrm{~kg} \mathrm{ha}^{-1}$. The lowest cowpea biomass yield was recorded under the control with $618.5 \mathrm{~kg} \mathrm{ha}^{-1}$. Means separation showed that there was no significant difference between the other treatments and the control. In 2018, biodeposit treatment (Agro + Elixir) + the recommended mineral fertilizer gave the highest cowpea grain yield with $745.99 \mathrm{~kg} \mathrm{ha}^{-1}$, followed by organova + recommended mineral fertilization $\left(735.13 \mathrm{~kg} \mathrm{ha}^{-1}\right)$.

Cowpea biomass yield with sole Organova application was lower compared to the recommended mineral fertilizer treatment in 2017, but a higher yield compared to the same treatment in 2018. On the other hand, Biodeposit (Agro + Elixir) treatment recorded lower cowpea grain yield compared to the recommended mineral fertilizer treatment across the two years.

Table 3. Cowpea biomass yield as affected by fertilizer

\begin{tabular}{lll}
\hline Treatments & $\mathbf{2 0 1 7}$ & $\mathbf{2 0 1 8}$ \\
\hline Control (without fertlizer application) & $618.5^{\mathrm{b}}$ & $383.84^{\mathrm{b}}$ \\
Recommended Mineral Fertilizer & $1242.4^{\mathrm{ab}}$ & $645.62^{\mathrm{a}}$ \\
Biodeposit (Agro + Elixir) & $813.8^{\mathrm{ab}}$ & $504.56^{\mathrm{ab}}$ \\
Biodeposit (Agro + Elixir) + Recommended Mineral Fertilizer & $998.3^{\mathrm{ab}}$ & $745.99^{\mathrm{a}}$ \\
Biodeposit (Agro + Elixir) + 1/2 Recommended Mineral Fertilizer & $1139.3^{\mathrm{ab}}$ & $697.16^{\mathrm{a}}$ \\
Organova & $938.6^{\mathrm{ab}}$ & $724.28^{\mathrm{a}}$ \\
Organova + Recommended Mineral Fertilizer & $1350.9^{\mathrm{a}}$ & $735.13^{\mathrm{a}}$ \\
Organova + 1/2 Recommended Mineral Fertilizer & $1133.9^{\mathrm{ab}}$ & $718.86^{\mathrm{a}}$ \\
\hline Probability & 0.05 & 0.0013 \\
\hline
\end{tabular}

Note. The means followed by the same letter are not significantly different at $5 \%$ probability.

\section{Discussion}

The results revealed a low of cowpea productivity level with the control plots due to the low inherent soil fertility. These results corroborate those obtained by Ouedraogo et al. (2014). They would probably be explained by the low inherent soil fertility. Indeed, several studies in West Africa have blamed this factor as one of the major 
causes of low agricultural productivity (Koulibaly et al., 2010; Bationo \& Fening, 2018). Fertilizer application has increased cowpea grain and biomass yields. The supply of mineral fertilizers improves crop mineral nutrition and thus the crop yields. Also, organic matter provides nutrients to plants and contributes to the improvement of soil's chemical, physical, and biological properties; leading to sustainable soil fertility management and improved agricultural productivity (Lal, 2006., Bationo and Fening, 2018).

The addition of organic fertilizers such as Organova or Biodeposit (Agro + Elixir) improved cowpea grain and biomass yields compared to the control treatment. Several studies have highlighted cowpea response to different types of organic amendments (Madukwe et al., 2008; El-Sayed \& Abdelnaser, 2010; Adeoye et al., 2011; Kolawole et al., 2013; Omotoso, 2014; Ouedraogo et al., 2014).

The highest cowpea grain yield was obtained with the combination of organic and mineral fertilizers. This could be explained by the improvement of crop mineral nutrition due to improved nutrients availability and the improvement of soil physico-chemical and biological properties with organic fertilizer application. Similar results have been obtained by Mando et al. (2005), and Ouédraogo et al. (2007) in the Nord Sudan zone of Burkina Faso with sorghum.

\section{Conclusion}

This study has evaluated the cowpea response to fertilization. The results revealed that the contribution of organic fertilizers such as Organova or Biodeposit (Agro + Elixir) increased grain and biomass yields compared to the control. However, these yields are lower than those of the recommended mineral fertilizer. In addition, the combination of these organic fertilizers with the recommended mineral fertilizer improves yields. Organic fertilizers are efficient when they are applied in combination with the recommended chemical fertilization. In the context of scarcity of organic resources, organic fertilizers (Organova and Biodeposit Agro + Biodeposit Elixir) represent a promising alternative for agricultural productivity intensification, particularly cowpea.

\section{References}

Adeoye, P. A., Adebayo, S. E., \& Musa, J. J. (2011). Growth and yield response of Cowpea (Vigna unguiculata) to poultry and cattle manure as amendments on sandy loam soil plot. Agricultural Journal, 6(5), 218-221. https://doi.org/10.3923/aj.2011.218.221

Bationo, A., \& Fening, J. O. (2018). Soil Organic Carbon and Proper Fertilizer Recommendation. In A. Bationo, D. Ngaradoum, S. Youl, F. Lompo, \& J. O. Fening (Eds.), Improving the Profitability, Sustainability and Efficiency of Nutrients Through Site Specific Fertilizers Recommendation in West Africa Agro-Ecosystems (Vol. 2, pp. 1-10). Springer, Dordrecht. https://doi.org/10.1007/978-3-319-58789-9_1

Bationo, A., Kihara, J., Vanlauwe, B., Waswa, B., \& Kimetu, J. (2007). Soil organic carbon dynamics, functions and management in West African agro-ecosystems. Agricultural Systems, 94, 13-25. https://doi.org/10.1016/ j.agsy.2005.08.011

Bationo, A., Waswa, B., Abdou, A., Bado, B. V., Bonzi, M., Iwuafor, E., ... Sedogo, M. (2012). Overview of long term experiments in Africa. In A. Bationo, B. Waswa, J. Kihara, I. Adolwa, B. Vanlauwe, \& K. Saidou (Eds.), Lessons learned from long term soil fertility management experiments in Africa (pp. 1-26). Springer, Dordrecht. https://doi.org/10.1016/j.agsy.2005.08.011

El-Sayed, M. A., \& Elzaawely, A. A. (2010). Growth and Yield of Cowpea Plants in Response to Organic Fertilization. Australian Journal of Basic and Applied Sciences, 4(8), 3244-3249.

INSD. (2018). Annuaire Statistique 2017 (p. 393). Ministère de l'Economie, des Finances et du Développement, Institut National de la Statistique et de la Démographie.

Kolawole, G. O., Adigun, C. O., Akintade, B. O., Opaleye, O. A., \& Lawal, B. A. (2013). Organic Residues Affect Soil P Availability, Cowpea Yield and Nutrient Uptake on a Near Neutral P-Deficient Alfisol in Southwestern Nigeria. International Journal of Applied Agricultural and Apicultural Research, 9(1\&2), 81-90.

Koulibaly, B., Traoré, O., Dakuo, D., Zombré, P. N., \& Bondé, D. (2010). Effet de la gestion des résidus de récolte sur les rendements et les bilans culturaux d'une rotation cotton-maïs-sorgho au Burkina Faso. Tropicultura, 28(3), 184-189.

Lahmar, R., Bationo, A., Lamso, D. N., Guéro, Y., \& Tittonell, P. (2011). Tailoring conservation agriculture technologies to West Africa semi-arid zones: building on traditional local practices for soil restoration. Field Crops Research, 132, 158-167. https://doi.org/10.1016/j.fcr.2011.09.013 
Lal, R. (2006). Enhancing crop yields in the developing countries through restoration of the soil organic carbon pool in agricultural lands. Land Degradation and Development, 17, 197-209. https://doi.org/10.1002/ldr.696

Lal, R. (2011). Sequestering carbon in soils of agro-ecosystems. Food Policy, 36, S33-S39. https://doi.org/ 10.1016/j.foodpol.2010.12.001

Madukwe, D. K., Christo, I. E. C., \& Onuh, M. O. (2008). Effects of organic manure and cowpea (Vigna unguiculata (L.) Walp) varieties on the chemical properties of the soil and root nodulation. Science World Journal, 3(1), 43-46. https://doi.org/10.4314/swj.v3i1.51772

Mando, A., Bonzi, M., Wopereis, M. C. S., Lompo, F., \& Stroosnijder, L. (2005). Long-term effects of mineral and organic fertilization on soil organic matter fractions and sorghum yield under Sudano-Sahelian conditions. Soil Use and Manage., 21, 396-401. https://doi.org/10.1079/SUM2005339

Oke, S. O., \& Eyitayo, D. L. (2010). Growth and yield response of cowpea (Vigna unguiculata L. Walp.) to soils from different fallow physiognomies in the rainforest zone of Nigeria. Acta Bot. Croat., 69(2), 291-297.

Omotoso, S. O. (2014). Influence of NPK 15-15-15 fertilizer and pig manure on nutrient dynamics and production of cowpea, Vigna unguiculata L. Walp. American Journal of Agriculture and Forestry, 2(6), 267-273. https://doi.org/10.11648/j.ajaf.20140206.16

Ouédraogo, E., Brussaard, L., \& Stroosnijder, L. (2007). Soil macrofauna and organic amendment interactions affects soil carbon and crop performance in semi-arid West Africa. Biol. Fert. Soils, 44(2), 343-351. https://doi.org/10.1007/s00374-007-0211-0

Ouédraogo, J., Ouédraogo, E., \& Nacro, H. B. (2014). Effet de l'interaction entre des modes de gestion de fertilité et la macrofaune sur la productivité du niébé et du sorgho en zone nord soudanienne du Burkina Faso. International Journal of Biological and Chemical Sciences, 8(1), 104-114. https://doi.org/ 10.4314/ijbcs.v8i1.10

\section{Copyrights}

Copyright for this article is retained by the author(s), with first publication rights granted to the journal.

This is an open-access article distributed under the terms and conditions of the Creative Commons Attribution license (http://creativecommons.org/licenses/by/4.0/). 